\title{
Neonatal montage
}

Arayamparambil C. Anilkumar, MD

Neurology ${ }^{\circledR}$ 2019;92:196. doi:10.1212/WNL.0000000000006823

\section{Correspondence}

Dr. Anilkumar

anilpedneuro@gmail.com
As the electrode pops on your hiccups

The day of misery is just born.

The artifacts, starlings in murmuration

The oscillator, your heartbeats, your breathing

Then the pat on the back by your nurse

The swinging chair of your grandma.

You sleep.

The trace' alternant appears.

I watch you stretch.

More artifacts.

Then come the sharp waves like army ants.

I ignore a few.

They soon disappear behind the vertex.

Here come the delta brushes

Sharps return with a vengeance

Like tumbleweeds on the sand dunes.

The picket fences become corn fields.

You, stretch with a slight quiver

Your mother pushes a warm kiss on you

The low oxygen alarm sounds.

You are travelling in windows of green

Corn fields, then passages and more.

Sand dunes, with isolated bushes

Then army ants again on the right, and then left

Building picket fences and corn fields.

I lost count of your seizures; how many so far?

You stretch, staring at me through the camera.

Where will you be travelling next?

\section{MORE ONLINE}

\section{ค Audio}

Listen to Dr. Anilkumar read this poem.

NPub.org/515eic

Figure Neonatal EEG

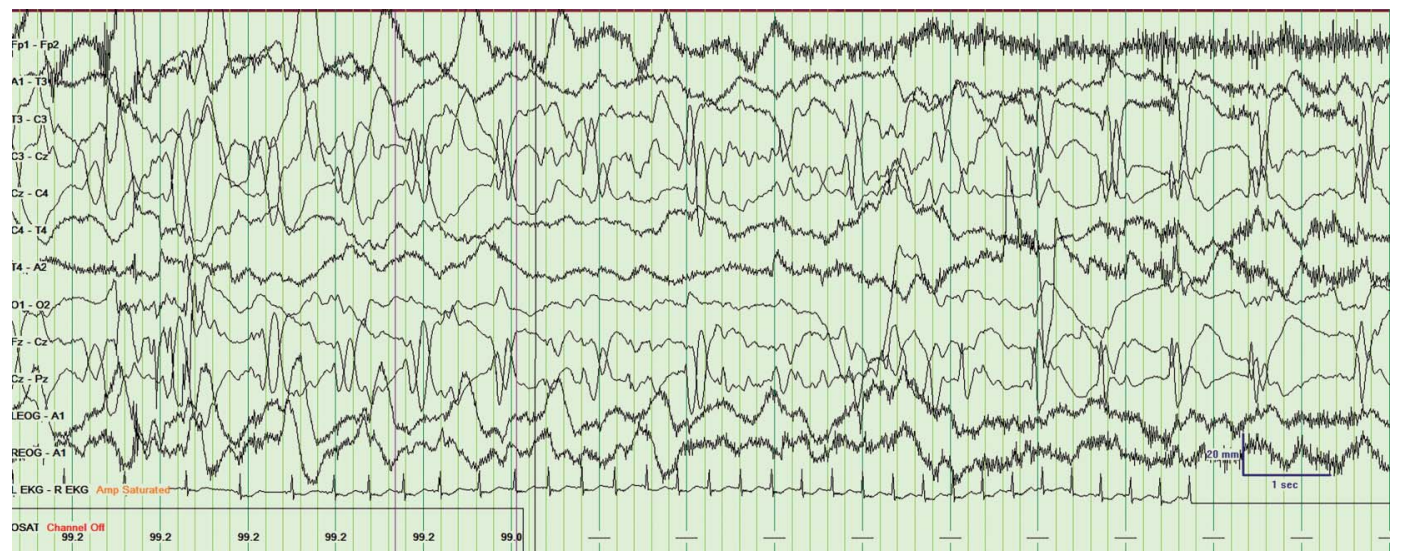




\title{
Neurology
}

\author{
Neonatal montage \\ Arayamparambil C. Anilkumar \\ Neurology 2019;92;196 \\ DOI 10.1212/WNL.0000000000006823
}

This information is current as of January 21, 2019

\section{Updated Information \& Services}

\section{Subspecialty Collections}

Permissions \& Licensing

Reprints including high resolution figures, can be found at: http://n.neurology.org/content/92/4/196.full

This article, along with others on similar topics, appears in the following collection(s):

\section{EEG; see Epilepsy/Seizures}

http://n.neurology.org/cgi/collection/eeg_see_epilepsy-seizures Epilepsy monitoring

http://n.neurology.org/cgi/collection/epilepsy_monitoring_ Neonatal

http://n.neurology.org/cgi/collection/neonatal

Neonatal seizures

http://n.neurology.org/cgi/collection/neonatal_seizures

Information about reproducing this article in parts (figures,tables) or in its entirety can be found online at:

http://www.neurology.org/about/about_the_journal\#permissions

Information about ordering reprints can be found online:

http://n.neurology.org/subscribers/advertise

Neurology ${ }^{\circledR}$ is the official journal of the American Academy of Neurology. Published continuously since 1951, it is now a weekly with 48 issues per year. Copyright @ 2019 American Academy of Neurology. All rights reserved. Print ISSN: 0028-3878. Online ISSN: 1526-632X.

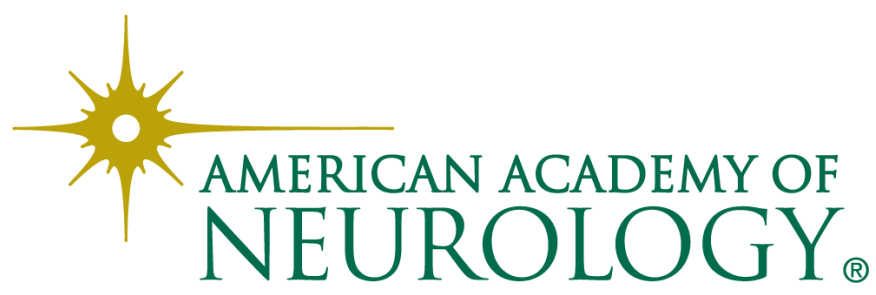

